\title{
Highly Reflective Dielectric Back Reflector for Improved Efficiency of Tandem Thin-Film Solar Cells
}

\author{
Chog Barugkin, ${ }^{1}$ Ulrich W. Paetzold, ${ }^{2}$ Kylie R. Catchpole, ${ }^{1}$ \\ Angelika Basch, ${ }^{3}$ and Reinhard Carius ${ }^{4}$ \\ ${ }^{1}$ The Australian National University, Canberra, ACT 2601, Australia \\ ${ }^{2}$ Karlsruhe Institute of Technology, 76344 Eggenstein-Leopoldshafen, Germany \\ ${ }^{3}$ Upper Austrian University of Applied Science, 4600 Wels, Austria \\ ${ }^{4}$ Forschungszentrum Jülich GmbH, 52425 Jülich, Germany
}

Correspondence should be addressed to Chog Barugkin; chog.barugkin@anu.edu.au

Received 22 July 2016; Accepted 28 August 2016

Academic Editor: Najeh Rekik

Copyright (c) 2016 Chog Barugkin et al. This is an open access article distributed under the Creative Commons Attribution License, which permits unrestricted use, distribution, and reproduction in any medium, provided the original work is properly cited.

\begin{abstract}
We report on the prototyping and development of a highly reflective dielectric back reflector for application in thin-film solar cells. The back reflector is fabricated by Snow Globe Coating (SGC), an innovative, simple, and cheap process to deposit a uniform layer of $\mathrm{TiO}_{2}$ particles which shows remarkably high reflectance over a broad spectrum (average reflectance of $99 \%$ from $500 \mathrm{~nm}$ to $1100 \mathrm{~nm}$ ). We apply the highly reflective back reflector to tandem thin-film silicon solar cells and compare its performance with conventional $\mathrm{ZnO}: \mathrm{Al} / \mathrm{Ag}$ reflector. By using SGC back reflector, an enhancement of $0.5 \mathrm{~mA} / \mathrm{cm}^{2}$ in external quantum efficiency of the bottom solar cell and an absolute value of $0.2 \%$ enhancement in overall power conversion efficiency are achieved. We also show that the increase in power conversion efficiency is due to the reduction of parasitic absorption at the back contact; that is, the use of the dielectric reflector avoids plasmonic losses at the reference $\mathrm{ZnO}: \mathrm{Al} / \mathrm{Ag}$ back reflector. The Snow Globe Coating process is compatible with other types of solar cells such as crystalline silicon, III-V, and organic photovoltaics. Due to its cost effectiveness, stability, and excellent reflectivity above a wavelength of $400 \mathrm{~nm}$, it has high potential to be applied in industry.
\end{abstract}

\section{Introduction}

Thin-film solar cells are very promising candidates for cost effective and high efficient photovoltaics. Several of the existing and developing thin-film solar cell technologies, for example, made of organic materials or thin silicon layers, apply physically and optically thin absorber layers and thus require light trapping concepts [1-6] as well as highly reflective back reflectors [7-10] to achieve high efficiencies. In this work, we report on the fabrication, prototyping, and implementation of a highly reflective dielectric back reflector prepared by the Snow Globe Coating (SGC) technique which is a simple and cheap method to form a uniform layer of $\mathrm{TiO}_{2}$ particles.

In order to demonstrate the superiority of SGC back reflector, we test it on tandem thin-film silicon solar cells and compare its performance with conventional $\mathrm{ZnO}: \mathrm{Al} / \mathrm{Ag}$ back reflectors which have proven their excellent performance in thin-film silicon solar cells [11-13]. For tandem thinfilm silicon solar cells which consist of a hydrogenated amorphous silicon (a-Si:H) top solar cell and a hydrogenated microcrystalline silicon ( $\mu \mathrm{c}$-Si:H) bottom solar cell, light management at the rear side is crucial to achieve high short circuit current density, as the $\mu \mathrm{c}-\mathrm{Si}: \mathrm{H}$ bottom solar cell absorbs weakly in the wavelength range from around $550 \mathrm{~nm}$ to $1100 \mathrm{~nm}[14,15]$. Improved reflectivity at the back reflector in tandem thin-film silicon solar cells will allow an increase of the charge carrier generation in the optically thin absorber layers and/or a reduction of the overall thickness of the tandem structure. In this way, the devices will benefit from improved power conversion efficiency and/or decreased deposition time and material, which will reduce the overall production costs per installed kWp. Moreover, reducing the thickness of the tandem thin-film silicon solar cells will result in better stability of the cells [16]. 
Diffuse reflectors such as white paint are widely investigated as back reflector (BR) and prove to be very effective for both crystalline silicon [17-19] and thin-film solar cells $[17,20-25]$. Compared to the alternative BR materials such as Ag, diffuse reflectors based on dielectric materials such as $\mathrm{TiO}_{2}$ have great potential for being applied as BR due to lower cost, better reflectivity, and lower parasitic absorptivity. A technique called Snow Globe Coating first described by Basch et al. in [25] is a simple and cheap way to form a layer of $\mathrm{TiO}_{2}$ diffuse reflector on the rear side of solar cells.

In this paper, we compare the optical and electrical performance of SGC back reflector and conventional $\mathrm{ZnO}: \mathrm{Al} / \mathrm{Ag}$ reflector on a-S:H/ $\mu \mathrm{c}-\mathrm{Si}: \mathrm{H}$ tandem thin-film silicon solar cells and demonstrate the outstanding characteristics of SGC with high reflection, low parasitic absorption, and compatibility with textured cell structure. By simulating the plasmon-induced optical losses on the surface of the conventional $\mathrm{ZnO}: \mathrm{Al} / \mathrm{Ag}$ reflector, we elaborate the physical reasons for better optical performance of SGC. External quantum efficiency (EQE), current-voltage $I-V$ characteristics, and absorptance $(A)$ spectra of the prototype solar cells are experimentally studied.

\section{Experiment}

2.1. Fabrication of Tandem Thin-Film Silicon Solar Cells. A three-dimensional (3D) schematic of the tandem thin-film silicon solar cell with SGC reflector is shown in Figure 1. Tandem thin-film silicon solar cells made of stacked a-Si:H top solar cell and a $\mu \mathrm{c}-\mathrm{Si}: \mathrm{H}$ bottom solar cell are prepared on as-grown textured commercially available $\mathrm{SnO}_{2}: \mathrm{F}$ superstrates (Asahi U-type from Asahi Glass Company [26]). The p-doped, intrinsic, and n-doped a-Si:H and $\mu \mathrm{c}$-Si:H layers of the solar cells are deposited using a single-chamber plasma enhanced chemical vapor deposition process (PECVD) at a frequency of $13.56 \mathrm{MHz}$. More details on our deposition process of the solar cells can be found in [27]. On the rear side of the bottom solar cell, $80 \mathrm{~nm} \mathrm{ZnO}: \mathrm{Al}$ is sputtered, followed by a few nanometers $(<5 \mathrm{~nm})$ of $\mathrm{SiO}_{2}$ as a capping layer. The $\mathrm{SiO}_{2}$ layer maintains the stability of $\mathrm{ZnO}$ :Al in water during the Snow Globe Coating process [28] and provides sufficient ohmic contact for carrier collection. Then $700 \mathrm{~nm}$ of cross-finger Ag contact is thermally evaporated through a shadow mask with $2 \mathrm{~mm}$ pitch (as shown in Figure 1) to minimize the Ag covered area as well as maintaining good electrical conductivity. Finally, a $\mathrm{TiO}_{2}$ back reflector is fabricated by using the Snow Globe Coating technique, as described in the following section. In order to achieve the most relevant comparison between two types of back reflectors, after characterization the SGC reflector is removed and a layer of $700 \mathrm{~nm}$ thermally evaporated Ag is deposited on the same cells to define the conventional $\mathrm{ZnO}: \mathrm{Al} / \mathrm{Ag}$ back reflector which is used as the reference structure in this experiment.

2.2. Highly Reflective Back Reflectors with the Snow Globe Coating Process. The Snow Globe Coating process is based on commercially available titanium dioxide particles with

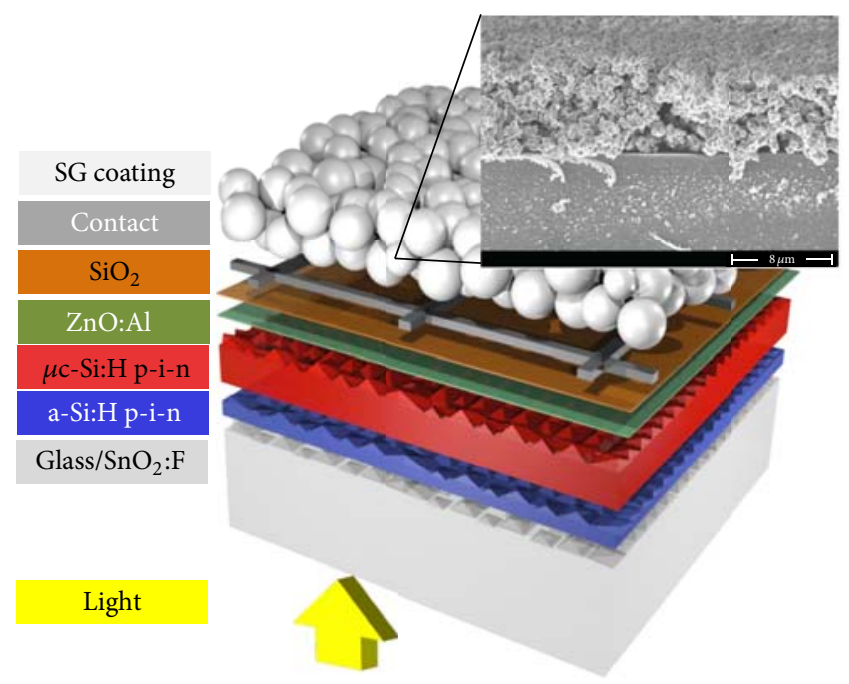

FIGURE 1: Three-dimensional schematic illustration of tandem thinfilm silicon solar cell with hydrogenated amorphous silicon top solar cell and hydrogenated microcrystalline silicon bottom solar cell, deposited on Asahi U-type $\left(\mathrm{SnO}_{2}: \mathrm{F}\right)$ coated glass substrate (not to scale). The back side structure consists of $80 \mathrm{~nm}$ sputtered $\mathrm{ZnO}: \mathrm{Al}$ and evaporated $\mathrm{SiO}_{2}$, cross-finger $\mathrm{Ag}$ contact and Snow Globe Coating $\mathrm{TiO}_{2}$ as back reflector. A scanning electron microscopy image of SGC is presented on the top right side of the figure.

average diameter of around $1 \mu \mathrm{m}\left(\mathrm{TiO}_{2}-100, \mathrm{~L} 32090\right.$ Auftrag no. 4497, Treibach-Althofen, Austria). A suspension of $\mathrm{TiO}_{2}$ particles with concentration of $0.5 \mathrm{wt} \%$ in $1000 \mathrm{~mL}$ deionized water is prepared in ultrasonic bath for $20 \mathrm{~min}$. The tandem thin-film silicon solar cells are located at the bottom of a beaker and the suspension is slowly poured into the beaker. The mixture is left to stand for two hours until the particles settle; then the water is drawn out leaving $\mathrm{TiO}_{2}$ on the cells for drying at room temperature.

2.3. Characterization Methods. External quantum efficiency (EQE) of the top cell and bottom cell is measured separately. In order to measure one subcell, current density saturation of the other subcell is needed since the cells are connected in series. For top cell measurement from $300 \mathrm{~nm}$ to $800 \mathrm{~nm}$, a bias light with RG695 filter is applied to saturate the bottom cell; an IF450 filtered bias light is used to saturate the top cell and measure the bottom cell from $450 \mathrm{~nm}$ to $1100 \mathrm{~nm}$. The current-voltage $I-V$ characterizations are performed with a Wacom Class A (AM 1.5) solar simulator with a power density of $100 \mathrm{~mW} / \mathrm{cm}^{2}$ (AM 1.5) at a constant temperature of $25^{\circ} \mathrm{C}$.

We have also measured the optical properties of various types of back reflectors including SGC back reflectors, textured $\mathrm{ZnO}: \mathrm{Al} / \mathrm{Ag}$ back reflectors prepared on a textured substrate, and super flat $\mathrm{ZnO}: \mathrm{Al} / \mathrm{Ag}$ on glass substrates using a dual beam Perkin Elmer LAMBDA 950 (UV-VisNIR) spectrophotometer with integrating sphere. The same optical characterization method is applied on tandem thinfilm silicon solar cells with SGC and conventional $\mathrm{ZnO}: \mathrm{Al} / \mathrm{Ag}$ back reflectors. 


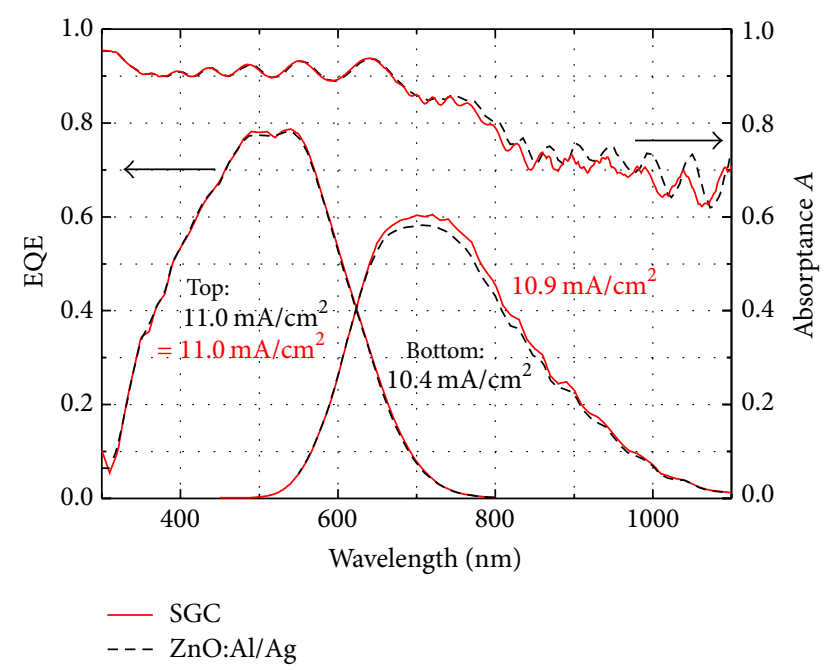

FIgURE 2: External quantum efficiency (EQE) (left $y$-axis) and absorptance $(A)$ (right $y$-axis) of the a-Si:H top solar cell and $\mu \mathrm{c}$ $\mathrm{Si}: \mathrm{H}$ bottom solar cell with $\mathrm{ZnO}: \mathrm{Al} / \mathrm{Ag}$ reflector (black dash line) and SGC reflector (red solid line).

\section{Result and Discussion}

3.1. Tandem Thin-Film Silicon Solar Cells Employing Snow Globe Coating Reflector. In Figure 2, the EQE and absorptance $A$ of tandem thin-film solar cells with SGC back reflectors and $\mathrm{ZnO}: \mathrm{Al} / \mathrm{Ag}$ back reflector are presented. The absorptance of each structure is obtained by reflectance measurements via $A=1-R$ (where $R$ is measured reflectance since the transmittance is zero). EQE results of the top cells $(\mathrm{a}-\mathrm{Si}: \mathrm{H})$ with SGC back reflector and the standard back reflector are almost identical at the wavelength range of $300-800 \mathrm{~nm}$. This underlines the comparability of the performance of the tandem cells with two different rear structures. In contrast, for the bottom cell ( $\mu \mathrm{c}-\mathrm{Si}: \mathrm{H})$ from $450 \mathrm{~nm}$ to $1100 \mathrm{~nm}, \mathrm{EQE}$ is improved significantly in the wavelength range from $650 \mathrm{~nm}$ to $1100 \mathrm{~nm}$. The short circuit current density $J_{\mathrm{SC}}$ of the bottom solar cell increases from $10.4 \mathrm{~mA} / \mathrm{cm}^{2}$ with conventional $\mathrm{ZnO}: \mathrm{Al} / \mathrm{Ag}$ back reflector to $10.9 \mathrm{~mA} / \mathrm{cm}^{2}$ with SGC back reflector (shown in Figure 2). This enhancement clearly indicates the better optical performance of the solar cell with the SGC back reflector compared to the cell with $\mathrm{ZnO}: \mathrm{Al} / \mathrm{Ag}$ reflector. As we can see from Figure 2 (right $y$-axis), absorption spectra of the cells with the two types of reflectors are identical for wavelengths shorter than $650 \mathrm{~nm}$. The optical impact of back reflectors comes in the wavelength range $\lambda>650 \mathrm{~nm}$, where the photons bounce once or more times within the structure and then escape through the front side of the solar cell. In this wavelength range, the absorptance of the solar cell with the SGC back reflector is slightly lower than the solar cell with the $\mathrm{ZnO}: \mathrm{Al} / \mathrm{Ag}$ back reflector. In combination with the EQE results, this is evidence that there is a larger portion of the absorbed light which does not contribute to the photocurrent generation in the solar cells with $\mathrm{ZnO}: \mathrm{Al} / \mathrm{Ag}$ back reflector. In other words, there is significant optical

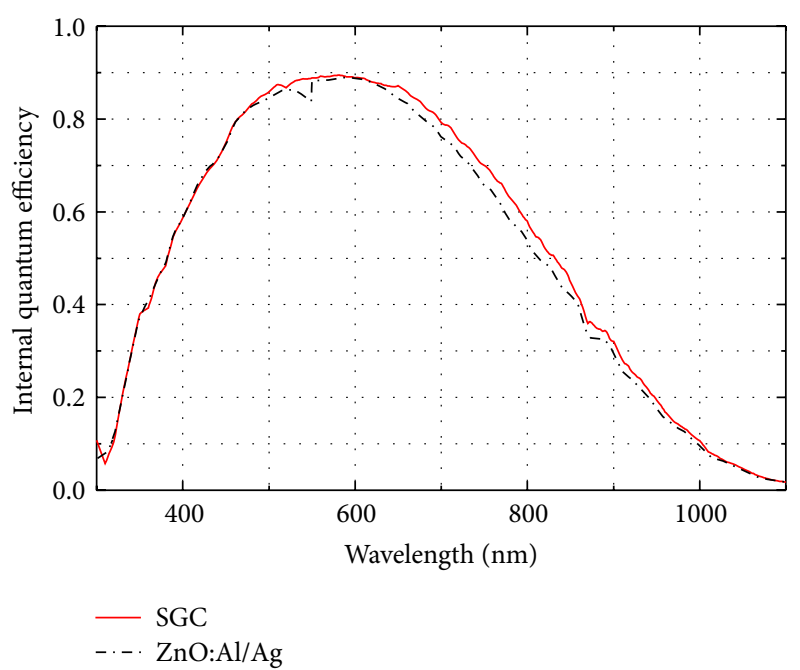

FIGURE 3: The total internal quantum efficiency (IQE) of tandem thin-film silicon solar cells with $\mathrm{ZnO}: \mathrm{Al} / \mathrm{Ag}$ back reflector (black dash line) and SGC back reflector (red line).

TABLE 1: Light $I-V$ characteristics of a-Si:H/ $\mu$ c-Si:H tandem solar cells with $\mathrm{ZnO}: \mathrm{Al} / \mathrm{Ag}$ back reflector and SGC back reflector.

\begin{tabular}{lcccc}
\hline Back reflector & $J_{\text {sc }}\left(\mathrm{mA} / \mathrm{cm}^{2}\right)$ & $\mathrm{FF} \%$ & $V_{\text {oc }}(\mathrm{mV})$ & $\eta \%$ \\
\hline SGC & 10.9 & 71 & 1350 & 10.4 \\
ZnO:Al/Ag & 10.4 & 72 & 1367 & 10.2 \\
\hline
\end{tabular}

loss in the conventional back reflector compared to SGC back reflector. With lower overall absorptance but a higher portion coming from the active layers, the cell with SGC back reflector outperforms the one with conventional $\mathrm{ZnO}: \mathrm{A} / \mathrm{Ag}$ back reflector in terms of photocurrent generation.

Figure 3 shows the total internal quantum efficiency (IQE) defined by the fraction of collected carriers per photon absorbed. The results clearly indicate that a larger number of carriers are generated in the tandem thin-film silicon solar cell with SGC back reflector compared to the cell with $\mathrm{ZnO}: \mathrm{Al} / \mathrm{Ag}$ back reflector.

The $I-V$ characterizations of tandem thin-film silicon solar cells with both types of back reflectors are presented in Table 1. The SGC back reflector sample has slightly lower fill factor $\mathrm{FF}(71 \%$ to $72 \%)$ and open circuit voltage $V_{\mathrm{oc}}$ $(1350 \mathrm{mV}$ to $1367 \mathrm{mV}$ ) than the one with $\mathrm{ZnO}: \mathrm{Al} / \mathrm{Ag}$ back reflector. This small degradation in FF of the tandem thinfilm silicon solar cells with SGC back reflector is caused by the different photocurrent mismatch of the component cells and the application of the cross-finger contact, which has a slightly lower collection efficiency than the conventional $\mathrm{ZnO}: \mathrm{Al} / \mathrm{Ag}$ back reflector, but less than $10 \%$ of the Ag consumption. The reason for small $V_{\mathrm{oc}}$ degradation is unclear and requires further investigation to clarify. However, the optical advantage of the SGC back reflector compensates the electrical loss and improves the overall efficiency by an absolute value of $0.2 \%$.

The state-of-the-art tandem a-Si:H/ $\mu \mathrm{c}-\mathrm{Si}: \mathrm{H}$ solar cells have achieved initial efficiency of over $13.5 \%$ and stabilized 
at around $12 \%$ on the sized cells in laboratory scale [15, $29-32]$ and the module efficiency of over $10 \%[15,30,31]$. The tandem solar cells that are used in this experiment are fabricated with standard process reported in [27]. The overall characteristics are less outstanding than cells with record efficiencies. However, the main focus of this study is trying to demonstrate the experimental proof of the concept of better performing diffuse dielectric reflector than the conventional metal reflector on a promising device configuration. On top of that the optical performance of the reference back reflector is comparable to the best known back reflector $[33,34]$. The result of higher efficiency of SG coated sample confirms our assumption. Since the efficiency gain is mostly due to the short circuit current enhancement, a higher overall conversion efficiency increase for the SG coated cells can be expected on an electrically optimized device.

In conclusion, the SGC back reflector outperforms the conventional $\mathrm{ZnO}: \mathrm{Al} / \mathrm{Ag}$ back reflector because of its higher reflectivity and lower parasitic absorptivity over a broad spectral range. In the following section, we make a detailed explanation of the reasons for the better optical performance of SGC reflector compared to the $\mathrm{ZnO}: \mathrm{Al} / \mathrm{Ag}$ reflector.

3.2. Absorptance of SGC Back Reflectors and Conventional $\mathrm{ZnO}: \mathrm{Al} / \mathrm{Ag}$ Back Reflectors. We present absorptance $A$ of SGC and standard textured $\mathrm{ZnO}: \mathrm{Al} / \mathrm{Ag}$ back reflector, as well as a special type of super flat $\mathrm{ZnO}: \mathrm{Al} / \mathrm{Ag}$ as a function of wavelength in Figure 4. SGC back reflector shows close to $0 \%$ absorptance above $400 \mathrm{~nm}$ wavelength which indicates much lower parasitic absorption compared to the randomly textured $\mathrm{ZnO}: \mathrm{Al} / \mathrm{Ag}$ back reflector. The reflectance is even comparable to or lower than the super flat $\mathrm{ZnO}: \mathrm{Al} / \mathrm{Ag}$ back reflector for wavelengths beyond $450 \mathrm{~nm}$. The super flat $\mathrm{Ag}$ structure was prepared by template stripping of an evaporated Ag layer from a conventional Si wafer with atomic scale flatness [35]. This layer serves as an optimal reference here and has proven to have excellent reflectivity in the literature $[9,35$, 36]. For the textured $\mathrm{ZnO}: \mathrm{Al} / \mathrm{Ag}$ back reflector, which is comparable to the $\mathrm{ZnO}: \mathrm{Al} / \mathrm{Ag}$ back reflector applied on tandem thin-film silicon solar cells in the previous section, significant parasitic absorptance is measured for wavelengths longer than $400 \mathrm{~nm}$. The enhanced absorption in the $\mathrm{ZnO}: \mathrm{Al} / \mathrm{Ag}$ back reflector introduces optical losses to the solar cells. This leads to lower EQE for wavelengths longer than around $550 \mathrm{~nm}$ where the incident light impinges multiple times at the rear reflector due to the light trapping effect of the randomly textured front side. Moreover, absorptance $A$ shows a specific characteristic including a distinct absorptance peak at wavelengths around $425 \mathrm{~nm}$ (Figure 4, blue dashed line). This peak is accompanied by an absorption tail that extends significantly into the wavelength range $(500 \mathrm{~nm}<\lambda<$ $1100 \mathrm{~nm}$ ). The enhanced parasitic absorptance could be due to two types of plasmonic losses which appear at textured Ag surfaces, namely, dissipative surface plasmon polariton (SPP) resonances [37-40] at the textured $\mathrm{ZnO}: \mathrm{Al} / \mathrm{Ag}[8,41$, 42] interface as well as dissipative localized surface plasmon (LSP) resonances $[43,44]$ at protrusions of the textured $\mathrm{ZnO}: \mathrm{Al} / \mathrm{Ag}$ interface [45-47]. These plasmonic losses are

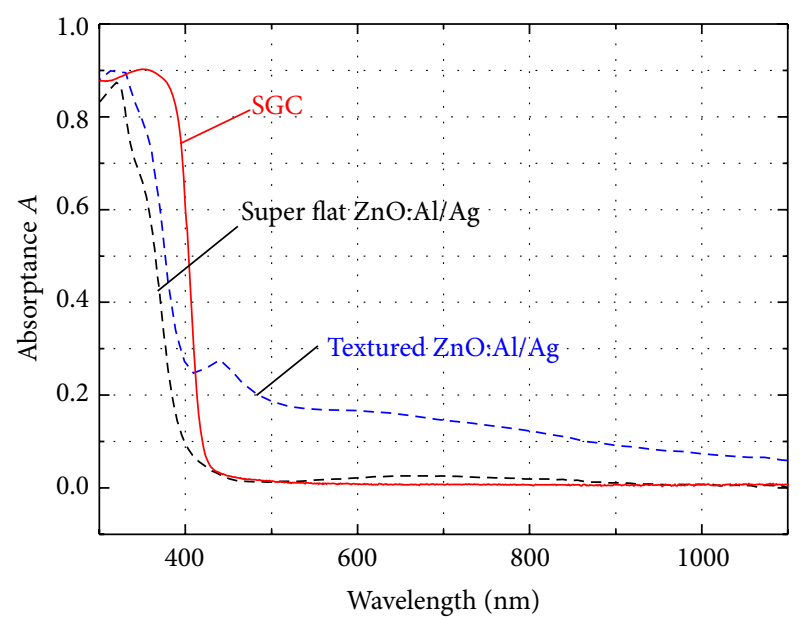

FIgURE 4: Absorptance $(A=1-R)$ of three different back reflectors: textured $\mathrm{ZnO}: \mathrm{Al} / \mathrm{Ag}$ (blue dashed line), super flat $\mathrm{ZnO}: \mathrm{Al} / \mathrm{Ag}$ back reflector (black dash line), and Snow Globe Coating back reflector (red solid line).

clearly related to the textured $\mathrm{ZnO}: \mathrm{Al} / \mathrm{Ag}$ interface since they are not apparent on the absorptance spectrum of the super flat $\mathrm{ZnO}: \mathrm{Al} / \mathrm{Ag}$ interface.

In order to discuss the plasmon-induced absorption of incident light at textured surfaces of Ag back reflector, the absorptance of thick Ag layers covered by $\mathrm{ZnO}: \mathrm{Al}$ is studied using theoretical methods. We begin by investigating the possible contribution of SPP resonances to the parasitic absorption of textured $\mathrm{ZnO}: \mathrm{Al} / \mathrm{Ag}$ reflectors. SPP resonances are electromagnetic eigenmodes which propagate along the metal/dielectric interface with a wave-vector $\left(k_{\|}\right)$parallel to the interface. The dispersion relation of the SPP eigenmodes at a flat $\mathrm{ZnO}: \mathrm{Al} / \mathrm{Ag}$ interface is calculated according to the following equation [44]:

$$
k_{\|}=\frac{\omega}{c} \cdot \sqrt{\frac{\epsilon_{m}(\omega) \epsilon_{D}(\omega)}{\epsilon_{m}(\omega)+\epsilon_{D}(\omega)}},
$$

where $\omega$ is the angular frequency of the photon and $c$ is the speed of the light in the medium. $\epsilon_{D}(\omega)$ and $\epsilon_{m}(\omega)$ denote the dielectric function of the dielectric and metal, respectively. In Figure 5(a), the spectral dependence of $k_{\|}$(calculated by (1)) of SPP modes at a flat $\mathrm{ZnO}: \mathrm{Al} / \mathrm{Ag}$ interface is shown. As the incident light at normal angle exhibits no component of the wave-vector parallel to the Ag surface (i.e., $k_{\|}=0$ ), no coupling of light to the SPP modes at a flat interface is possible due to momentum conservation. Therefore, in order to allow coupling of incident light and SPP modes at the Ag surface, an additional wave-vector component $\left(\Delta k_{\|}\right)$must be provided by scattering at the randomly textured $\mathrm{Ag}$ surface. As shown in Figure 5(a), at the resonance wavelength $\left(\lambda_{\mathrm{SPP}}\right)$, the density of suitable wave-vector components $\left(\Delta k_{\|}\right)$per wavelength interval is strongly enhanced. Thus, the excitation of propagating SPP modes is much more probable. Due to the damping of the SPP modes, the enhanced excitation of SPP modes leads to enhanced absorptance of incident light at randomly textured Ag surfaces at $\lambda_{\mathrm{SPP}}$. Thus, the absorptance 


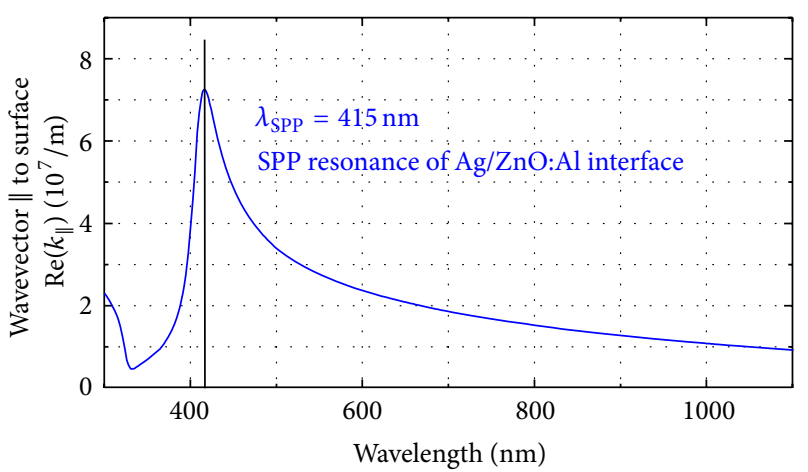

(a)

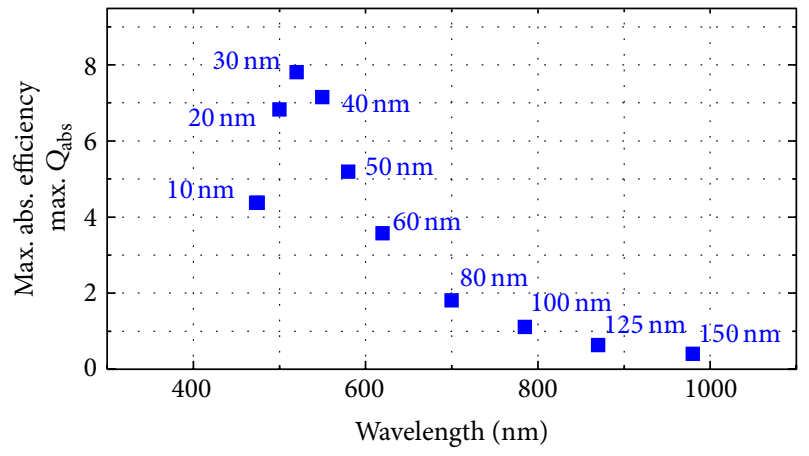

(b)

FIGURE 5: (a) Dispersion relation of SPP modes calculated according to (1). SPP modes propagating along a flat Ag surface covered with $\mathrm{ZnO}: \mathrm{Al}$ half space as a function of the real part of the wave-vector parallel to the surface $\left(k_{\|}\right)$. (b) Maxima in simulated absorption efficiency (max. $Q_{a b s}$ ) of LSP resonances in hemispherical Ag nanostructures as a function of the resonance wavelength $\left(\lambda_{\text {res }}\right)$ covered by $\mathrm{ZnO}: \mathrm{Al}$. The radius of the hemispherical nanostructure is varied from $10 \mathrm{~nm}$ to $150 \mathrm{~nm}$.

peak of the randomly textured $\mathrm{ZnO}: \mathrm{Al} / \mathrm{Ag}$ surface at the wavelength around $425 \mathrm{~nm}$ can be explained by coupling of the light to SPP modes at the randomly textured Ag surfaces.

Localized surface plasmons are also well known to induce optical losses at small Ag nanostructures [40, 43]. In Figure 5(b), the simulated maximum values of the absorption efficiency $\left(\max . Q_{\mathrm{abs}}\right.$ ) at the dominant LSP resonance of hemispherical Ag nanostructures embedded in $\mathrm{ZnO}: \mathrm{Al}$ are shown. The three-dimensional electromagnetic simulations are conducted with commercially available software JCMwave which was used extensively in previous studies to investigate at high precision localized plasmonic effects in Ag nanostructures [45]. For the investigated hemispherical $\mathrm{Ag}$ nanostructures embedded in $\mathrm{ZnO}: \mathrm{Al}$, strong absorptance is found. The absorption efficiency $\left(Q_{a b s}\right)$ denotes the absorbed intensity of incident light normalized by the intensity irradiated on the cross section of the nanostructures. In other words, if $Q_{a b s}=1$ the entire light incident on the cross section of nanostructure is absorbed. Considering the values of $Q_{a b s}$ shown in Figure 5(b) which are well above 1 for small nanostructures with radius $<100 \mathrm{~nm}$, a significant fraction of the light incident on a nanostructured $\mathrm{ZnO}: \mathrm{Al} / \mathrm{Ag}$ interface can be absorbed, even with a fill fraction of nanostructures well below unity. Similar strong absorption as a function of the resonance wavelength has been observed for other geometries of the nanostructures as well as coupled nanostructures [48]. For this reason, considering the broad distribution of shapes, sizes, and arrangements of $\mathrm{Ag}$ nanostructures at the randomly textured Ag surfaces, LSPinduced optical losses are expected to be significant on the Ag surfaces. Note that substantial LSP-induced losses are found in small nanostructures of radius below $100 \mathrm{~nm}$, which show strong nonradiative damping, in contrast to larger $\mathrm{Ag}$ nanostructures which have proven to show a beneficial strong light scattering effect [18, 49-53].

Both LSP and SPP resonances can be excited by incident light on randomly textured $\mathrm{Ag}$ surfaces such as the Ag back contacts of thin-film silicon solar cells with the state-ofthe-art random texture for light trapping. The agreement of the calculated $\lambda_{\mathrm{SPP}}$ with the spectral position of the absorptance maxima of the randomly textured $\mathrm{Ag}$ surfaces indicates that these absorptance maxima are likely to be caused by SPP-induced optical losses [7, 42]. However, the enhanced absorption at longer wavelengths on the surface of Ag back contacts with the random texture can be explained by both LSP-induced and SPP-induced optical losses. It is concluded that, for incident light of wavelengths longer than $500 \mathrm{~nm}$, both types of plasmonic effects induce parasitic absorptance at the textured Ag back contacts covered with $\mathrm{ZnO}$ :Al. Since these plasmonic losses are not apparent in the absorptance of the super flat $\mathrm{ZnO}: \mathrm{Al} / \mathrm{Ag}$ device shown for comparison in Figure 4, the plasmonic losses are related to the textured $\mathrm{ZnO}: \mathrm{Al} / \mathrm{Ag}$ interface. However, textured cell structures are essential to thin-film solar cells for providing light trapping [54]. Therefore, the highly reflective SGC back reflector examined in this study provides an alternative to this dilemma. SGC reflector provides excellent reflectivity comparable to a super flat $\mathrm{ZnO}: \mathrm{Al} / \mathrm{Ag}$ back reflector as well as allowing a textured cell structure to be maintained.

\section{Conclusion}

Localized and propagating plasmonic resonances excited by incident light on randomly textured $\mathrm{ZnO}: \mathrm{Al} / \mathrm{Ag}$ back contacts of thin-film silicon solar cells can introduce significant amount of parasitic absorption thereby reducing the overall cell performance. Dielectric diffuse reflectors prepared by SGC show close to $100 \%$ reflectance over a spectral range of 400-1100 nm which indicates much lower parasitic optical losses compared to the standard textured $\mathrm{ZnO}: \mathrm{Al} / \mathrm{Ag}$ reflector. By replacing $\mathrm{ZnO}: \mathrm{Al} / \mathrm{Ag}$ with SGC reflector on tandem thin-film silicon solar cells as a rear reflector, the overall cell efficiency can be improved from $10.2 \%$ to $10.4 \%$. Moreover, due to the relatively simple fabrication process of SGC reflector, it can be easily adapted to other types of solar cells such as mono/multicrystalline silicon solar cells, III$\mathrm{V}$ solar cells, and perovskite solar cells. Given the fact of parasitic absorption and higher cost of Ag, SGC reflector has a very promising future in the PV industry as a replacement of Ag back reflector due to excellent optical properties, cheap price, and massive production of $\mathrm{TiO}_{2}$. 


\section{Competing Interests}

The authors declare that there is no conflict of interests regarding the publication of this paper.

\section{Acknowledgments}

The authors would like to thank S. Gall and M. Weizman from HZB for the SEM image of SGC and T. Merdzhanova for helpful discussion.

\section{References}

[1] M. A. Green, Solar Cells: Operating Principles, Technology and System Applications, Prentice-Hall, Englewood Cliffs, NJ, USA, 1986.

[2] O. Kluth, B. Rech, L. Houben et al., "Texture etched $\mathrm{ZnO}$ :Al coated glass substrates for silicon based thin film solar cells," Thin Solid Films, vol. 351, no. 1-2, pp. 247-253, 1999.

[3] J. Müller, O. Kluth, S. Wieder et al., "Development of highly efficient thin film silicon solar cells on texture-etched zinc oxide-coated glass substrates," Solar Energy Materials and Solar Cells, vol. 66, no. 1-4, pp. 275-281, 2001.

[4] J. Escarré, K. Söderström, C. Battaglia, F.-J. Haug, and C. Ballif, "High fidelity transfer of nanometric random textures by UV embossing for thin film solar cells applications," Solar Energy Materials and Solar Cells, vol. 95, no. 3, pp. 881-886, 2011.

[5] M. Niggemann, M. Riede, A. Gombert, and K. Leo, "Light trapping in organic solar cells," Physica Status Solidi A, vol. 205, no. 12 , pp. 2862-2874, 2008.

[6] E. Yablonovitch and G. D. Cody, "Intensity enhancement in textured optical sheets for solar cells," IEEE Transactions on Electron Devices, vol. 29, no. 2, pp. 300-305, 1982.

[7] J. Springer, A. Poruba, L. Müllerova, M. Vanecek, O. Kluth, and B. Rech, "Absorption loss at nanorough silver back reflector of thin-film silicon solar cells," Journal of Applied Physics, vol. 95, no. 3, pp. 1427-1429, 2004.

[8] E. Moulin, U. W. Paetzold, K. Bittkau et al., "Investigation of the impact of the rear-dielectric/silver back reflector design on the optical performance of thin-film silicon solar cells by means of detached reflectors," Progress in Photovoltaics: Research and Applications, vol. 21, no. 5, pp. 1236-1247, 2013.

[9] E. Moulin, U. W. Paetzold, J. Kirchhoff, A. Bauer, and R. Carius, "Study of detached back reflector designs for thin-film silicon solar cells," Physica Status Solidi-Rapid Research Letters, vol. 6, no. 2, pp. 65-67, 2012.

[10] D. M. N. M. Dissanayake, B. Roberts, and P.-C. Ku, "Plasmonic backscattering enhanced inverted photovoltaics," Applied Physics Letters, vol. 99, no. 11, Article ID 113306, 2011.

[11] A. M. K. Dagamseh, B. Vet, F. D. Tichelaar, P. Sutta, and M. Zeman, "ZnO:Al films prepared by rf magnetron sputtering applied as back reflectors in thin-film silicon solar cells," Thin Solid Films, vol. 516, no. 21, pp. 7844-7850, 2008.

[12] E. Moulin, U. W. Paetzold, K. Bittkau et al., "Thin-film silicon solar cells applying optically decoupled back reflectors," Materials Science and Engineering B: Solid-State Materials for Advanced Technology, vol. 178, no. 9, pp. 645-650, 2013.

[13] M. Vanecek, O. Babchenko, A. Purkrt et al., "Nanostructured three-dimensional thin film silicon solar cells with very high efficiency potential," Applied Physics Letters, vol. 98, no. 16, Article ID 163503, 2011.
[14] A. V. Shah, M. Vaněček, J. Meier et al., "Basic efficiency limits, recent experimental results and novel light-trapping schemes in a-Si:H, $\mu \mathrm{c}-\mathrm{Si}: \mathrm{H}$ and 'micromorph tandem' solar cells," Journal of Non-Crystalline Solids, vol. 338-340, pp. 639-645, 2004.

[15] A. Shah, E. Moulin, and C. Ballif, "Technological status of plasma-deposited thin-film silicon photovoltaics," Solar Energy Materials and Solar Cells, vol. 119, pp. 311-316, 2013.

[16] S. Schicho, D. Hrunski, R. van Aubel, and A. Gordijn, "High potential of thin $(<1 \mu \mathrm{m})$ a-Si: H/ $\mu \mathrm{c}-\mathrm{Si}: \mathrm{H}$ tandem solar cells," Progress in Photovoltaics: Research and Applications, vol. 18, no. 2, pp. 83-89, 2010.

[17] J. E. Cotter, R. B. Hall, M. G. Mauk, and A. M. Barnett, "Light trapping in Silicon-Film ${ }^{\mathrm{TM}}$ solar cells with rear pigmented dielectric reflectors," Progress in Photovoltaics: Research and Applications, vol. 7, no. 4, pp. 261-274, 1999.

[18] C. Barugkin, Y. Wan, D. Macdonald, and K. R. Catchpole, "Evaluating plasmonic light trapping with photoluminescence," IEEE Journal of Photovoltaics, vol. 3, no. 4, pp. 1292-1297, 2013.

[19] C. Barugkin, T. Allen, T. K. Chong, T. P. White, K. J. Weber, and K. R. Catchpole, "Light trapping efficiency comparison of Si solar cell textures using spectral photoluminescence," Optics Express, vol. 23, no. 7, pp. A391-A400, 2015.

[20] J. E. Cotter, "Optical intensity of light in layers of silicon with rear diffuse reflectors," Journal of Applied Physics, vol. 84, no. 1, pp. 618-624, 1998.

[21] B. Lipovšek, J. Krč, O. Isabella, M. Zeman, and M. Topič, "Modeling and optimization of white paint back reflectors for thin-film silicon solar cells," Journal of Applied Physics, vol. 108, no. 10, Article ID 103115, 2010.

[22] B. Lipovšek, J. Krč, O. Isabella, M. Zeman, and M. Topič, "Analysis of thin-film silicon solar cells with white paint back reflectors," Physica Status Solidi (C) Current Topics in Solid State Physics, vol. 7, no. 3-4, pp. 1041-1044, 2010.

[23] O. Berger, D. Inns, and A. G. Aberle, "Commercial white paint as back surface reflector for thin-film solar cells," Solar Energy Materials and Solar Cells, vol. 91, no. 13, pp. 1215-1221, 2007.

[24] B. G. Lee, P. Stradins, D. L. Young et al., "Light trapping by a dielectric nanoparticle back reflector in film silicon solar cells," Applied Physics Letters, vol. 99, no. 6, Article ID 064101, 2011.

[25] A. Basch, F. Beck, T. Söderström, S. Varlamov, and K. R. Catchpole, "Enhanced light trapping in solar cells using snow globe coating," Progress in Photovoltaics: Research and Applications, vol. 20, no. 7, pp. 837-842, 2012.

[26] N. Taneda, K. Masumo, M. Kambe, T. Oyama, and K. Sato, "Highly textured $\mathrm{SnO}_{2}$ films for a-Si/ $\mu \mathrm{c}$-Si tandem solar cells," in Proceedings of the 3rd European Photovoltaic Solar Energy Conference and Exhibition, pp. 2084-2087, Valencia, Spain, September 2008.

[27] T. Merdzhanova, T. Zimmermann, U. Zastrow, A. Gordijn, and W. Beyer, "a-Si:H/ $\mu c-S i: H$ solar cells prepared by the singlechamber processes-minimization of phosphorus and boron cross contamination," Thin Solid Films, vol. 540, pp. 251-255, 2013.

[28] T. Miyata, Y. Ohtani, T. Kuboi, and T. Minami, "Stability of nano-thick transparent conducting oxide films for use in a moist environment," Thin Solid Films, vol. 516, no. 7, pp. 13541358, 2008.

[29] M. A. Green, K. Emery, Y. Hishikawa, W. Warta, and E. D. Dunlop, "Solar cell efficiency tables (version 41)," Progress in Photovoltaics: Research and Applications, vol. 21, no. 1, pp. 1-11, 2013. 
[30] A. Terakawa, "Review of thin-film silicon deposition techniques for high-efficiency solar cells developed at Panasonic/Sanyo," Solar Energy Materials and Solar Cells, vol. 119, pp. 204-208, 2013.

[31] B. Stannowski, O. Gabriel, S. Calnan et al., "Achievements and challenges in thin film silicon module production," Solar Energy Materials and Solar Cells, vol. 119, pp. 196-203, 2013.

[32] M. Despeisse, M. Boccard, C. Battaglia et al., "Light harvesting schemes for high efficiency thin film silicon solar cells," in Proceedings of the 38th IEEE Photovoltaic Specialists Conference (PVSC '12), pp. 3015-3019, Austin, Tex, USA, June 2012.

[33] S. Kim, H. Lee, J.-W. Chung, S.-W. Ahn, and H.-M. Lee, "nType microcrystalline silicon oxide layer and its application to high-performance back reflectors in thin-film silicon solar cells," Current Applied Physics, vol. 13, no. 4, pp. 743-747, 2013.

[34] B. Janthong, A. Hongsingthong, T. Krajangsang, L. Zhang, P. Sichanugrist, and M. Konagai, "Novel a-Si:H/ $\mu \mathrm{c}-\mathrm{Si}: \mathrm{H}$ tandem cell with lower optical loss," Journal of Non-Crystalline Solids, vol. 358, no. 17, pp. 2478-2481, 2012.

[35] P. Nagpal, N. C. Lindquist, S.-H. Oh, and D. J. Norris, "Ultrasmooth patterned metals for plasmonics and metamaterials," Science, vol. 325, no. 5940, pp. 594-597, 2009.

[36] H. Im, S. H. Lee, N. J. Wittenberg et al., “Template-stripped smooth Ag nanohole arrays with silica shells for surface plasmon resonance biosensing," ACS Nano, vol. 5, no. 8, pp. 62446253, 2011.

[37] H. Raether, Surface Plasmons on Smooth and Rough Surfaces and on Gratings, Springer, Berlin, Germany, 1988.

[38] C. Hägglund and B. Kasemo, "Nanoparticle plasmonics for 2Dphotovoltaics: mechanisms, optimization, and limits," Optics Express, vol. 17, no. 14, pp. 11944-11957, 2009.

[39] C. F. Bohren, "How can a particle absorb more than the light incident on it?" American Journal of Physics, vol. 51, no. 4, pp. 323-327, 1983.

[40] C. F. Bohren and D. R. Huffman, Absorption and Scattering of Light by Small Particles, John Wiley \& Sons, New York, NY, USA, 2008.

[41] J. Springer, B. Rech, W. Reetz, J. Müller, and M. Vanecek, "Light trapping and optical losses in microcrystalline silicon pin solar cells deposited on surface-textured glass/ZnO substrates," Solar Energy Materials and Solar Cells, vol. 85, no. 1, pp. 1-11, 2005.

[42] F.-J. Haug, T. Söderström, O. Cubero, V. Terrazzoni-Daudrix, and $\mathrm{C}$. Ballif, "Influence of the $\mathrm{ZnO}$ buffer on the guided mode structure in $\mathrm{Si} / \mathrm{ZnO} / \mathrm{Ag}$ multilayers," Journal of Applied Physics, vol. 106, no. 4, Article ID 044502, 2009.

[43] M. V. U. Kreibig, Optical Properties of Metal Clusters, Springer, Berlin, Germany, 1995.

[44] S. A. Maier, Plasmonics: Fundamentals and Applications, Springer, Berlin, Germany, 2007.

[45] U. W. Paetzold, E. Moulin, B. E. Pieters, R. Carius, and U. Rau, "Design of nanostructured plasmonic back contacts for thinfilm silicon solar cells," Optics Express, vol. 19, no. 23, pp. A1219A1230, 2011.

[46] V. E. Ferry, L. A. Sweatlock, D. Pacifici, and H. A. Atwater, "Plasmonic nanostructure design for efficient light coupling into solar cells," Nano Letters, vol. 8, no. 12, pp. 4391-4397, 2008.

[47] K. Jäger, M. Schulte, K. Bittkau et al., "Optical scattering properties of a nano-textured $\mathrm{ZnO}$-silicon interface," in Proceedings of the International Conference on Applications of Optics and Photonics, vol. 8001 of Proceedings of SPIE, Braga, Portugal, May 2011.
[48] U. W. Paetzold, F. Hallermann, B. E. Pieters, U. Rau, R. Carius, and G. von Plessen, "Localized plasmonic losses at metal back contacts of thin-film silicon solar cells," in Photonics for Solar Energy Systems III, vol. 7725 of Proceedings of SPIE, Brussels, Belgium, 2010.

[49] K. R. Catchpole and A. Polman, "Design principles for particle plasmon enhanced solar cells," Applied Physics Letters, vol. 93, no. 19, Article ID 191113, 2008.

[50] S. Mokkapati, F. J. Beck, A. Polman, and K. R. Catchpole, "Designing periodic arrays of metal nanoparticles for lighttrapping applications in solar cells," Applied Physics Letters, vol. 95, no. 5, Article ID 053115, 2009.

[51] V. E. Ferry, M. A. Verschuuren, H. B. T. Li et al., "Light trapping in ultrathin plasmonic solar cells," Optics Express, vol. 18, no. 13, pp. A237-A245, 2010.

[52] U. W. Paetzold, E. Moulin, B. E. Pieters, U. Rau, and R. Carius, "Optical simulations of microcrystalline silicon solar cells applying plasmonic reflection grating back contacts," Journal of Photonics for Energy, vol. 2, no. 1, Article ID 027002, 2012.

[53] D. Derkacs, S. H. Lim, P. Matheu, W. Mar, and E. T. Yu, "Improved performance of amorphous silicon solar cells via scattering from surface plasmon polaritons in nearby metallic nanoparticles," Applied Physics Letters, vol. 89, no. 9, Article ID 093103, 2006.

[54] K. Jäger, O. Isabella, L. Zhao, and M. Zeman, "Light scattering properties of surface-textured substrates," Physica Status Solidi C, vol. 7, no. 3-4, pp. 945-948, 2010. 

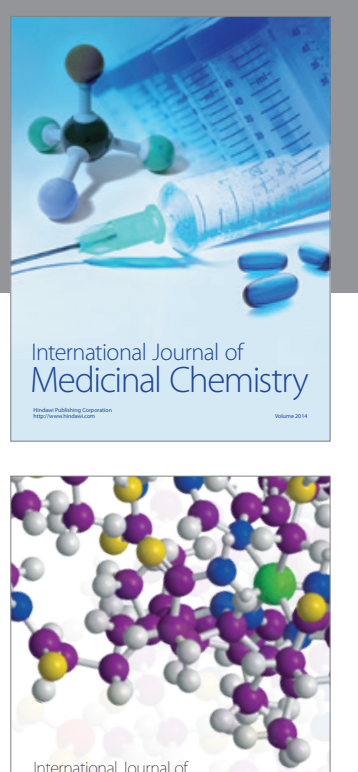

Carbohydrate Chemistry

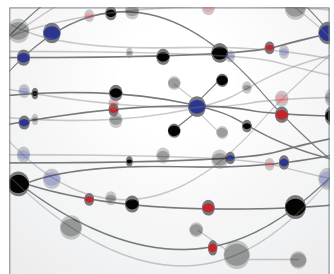

The Scientific World Journal
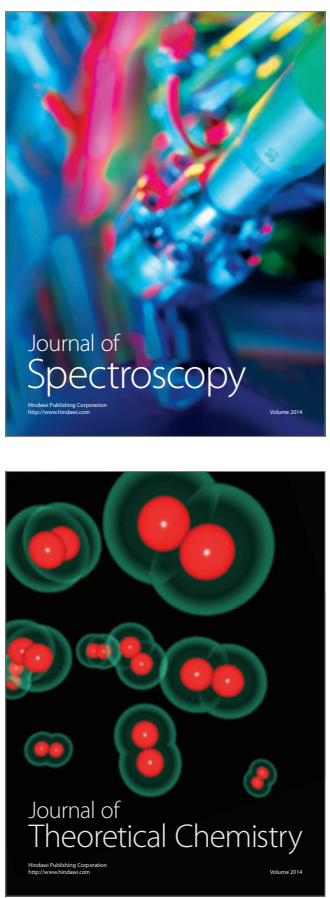
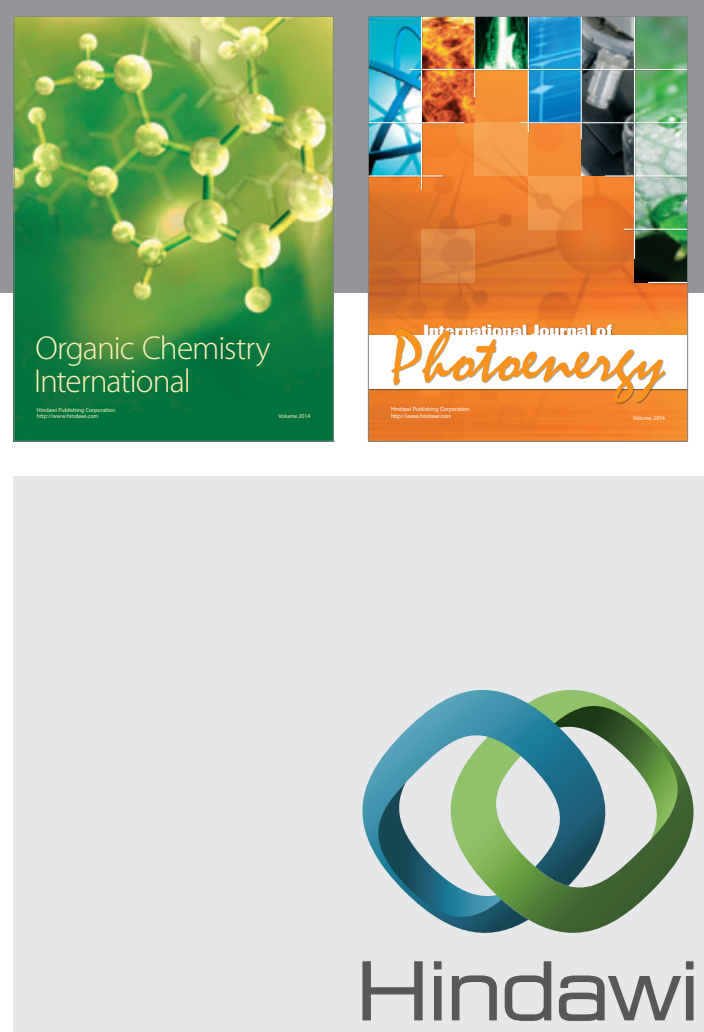

Submit your manuscripts at

http://www.hindawi.com

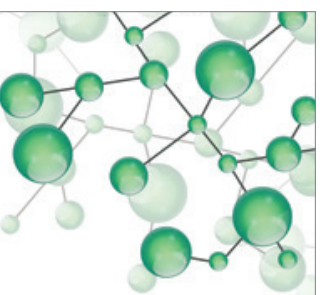

International Journal of

Inorganic Chemistry

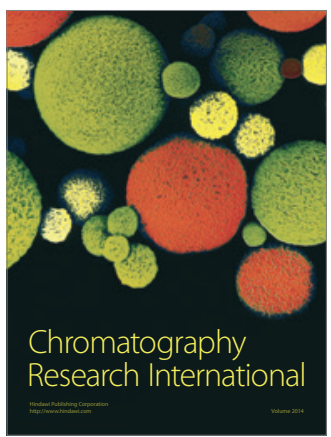

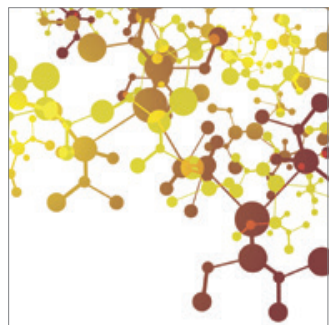

Applied Chemistry
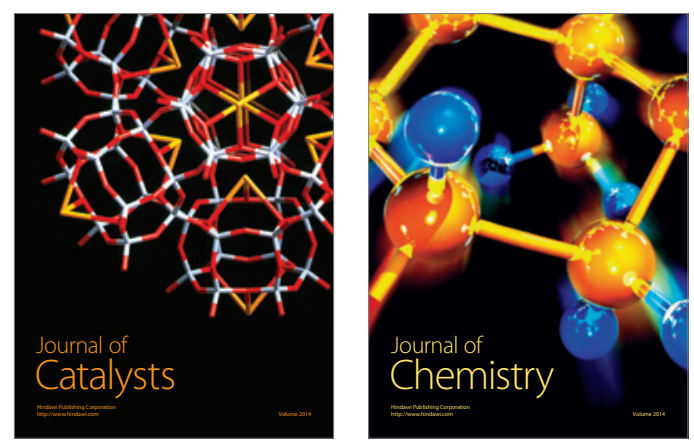
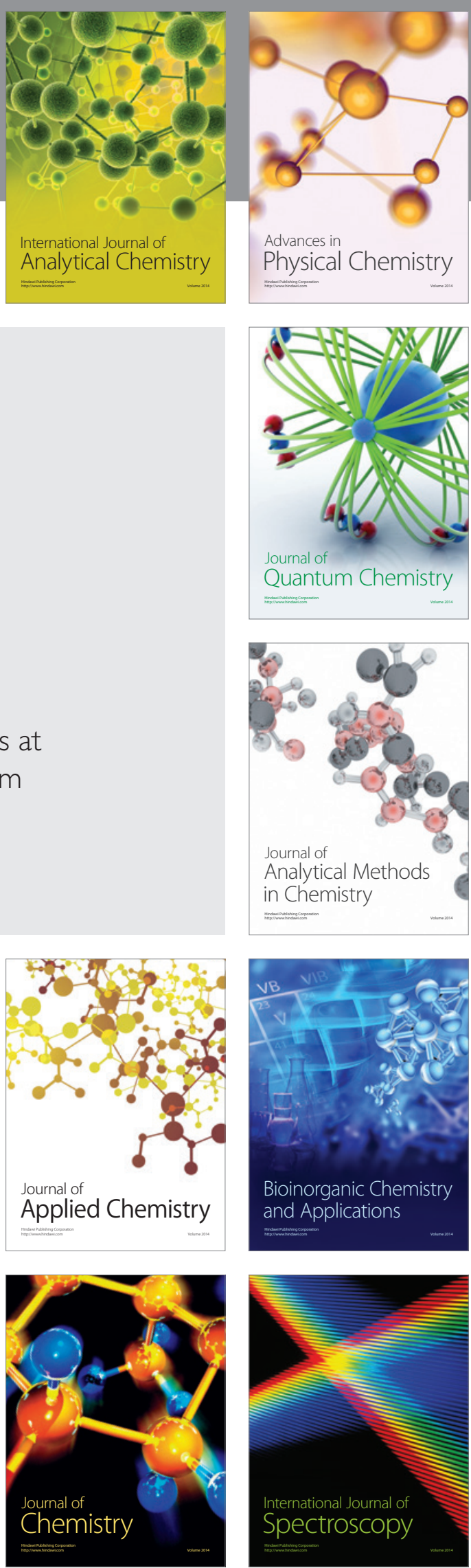